Research Article

\title{
Antibacterial Activity of Two Flavans from the Stem Bark of Embelia schimperi
}

\author{
Babe Guyasa, Yadessa Melaku (D), and Milkyas Endale (i) \\ Applied Chemistry Program, School of Applied Natural Science, Adama Science and Technology University, \\ P.O. Box 1888, Adama, Ethiopia
}

Correspondence should be addressed to Milkyas Endale; milkyasendale@yahoo.com

Received 11 October 2017; Accepted 29 March 2018; Published 30 April 2018

Academic Editor: Masahiro Oike

Copyright (C) 2018 Babe Guyasa et al. This is an open access article distributed under the Creative Commons Attribution License, which permits unrestricted use, distribution, and reproduction in any medium, provided the original work is properly cited.

Embelia schemperi Vatke is one of the medicinal plants used traditionally for treatment of intestinal tape worm, dysmenorrheal, bacterial, and fungal infections. Phytochemical screening test of the dichloromethane/methanol $(1: 1)$ and methanol extracts revealed the presence of phenols, alkaloids, tannins, and flavonoids whereas terpenoids, glycoside, and phytosterols were absent. Silica gel column chromatographic separation of the methanol extract afforded 3,5,7,3', $4^{\prime}$-pentahydroxyflavan, named epicatechin (1), along with a close flavan derivative (2). Structures of the compounds were elucidated by spectroscopic techniques (1D and 2D NMR, FTIR, and UV-Vis). The crude extracts and isolated compounds were screened for in vitro antibacterial activity against strains of Klebsiella pneumoniae, Escherichia coli, Cryptococcus neoformans, Shigella dysentriae, and Staphylococcus aureus. Epicatechin (1) exhibited comparable antibacterial activity against S. aureus and E. coli (15 and $12 \mathrm{~mm}$ zone of inhibition, resp.) to that of the control antibiotic gentamicin, with zone of inhibition of 15 and $12 \mathrm{~mm}$, respectively, at a concentration of $20 \mu \mathrm{g} / \mathrm{mL}$.

\section{Introduction}

Medicinal plants have been a major source of cure for human diseases since time of immemorial. As modern techniques, for example, genomics, high-throughput screening, and targetoriented drug development strategies, have not yet fulfilled the expectations that appeared promising upon their introduction, chemotherapeutics remain the cornerstone of patient management and will likely remain so for the foreseeable future. Rapid resistance development of microorganisms to existing medicines reveals the essential need for drugs with novel modes of action. Though a number of antibacterials have been reported from natural source or their derivatives, evaluation of plant-based indigenous medicines still appears as one of the promising sources of novel antibacterial leads.

Originating from its traditional use for the treatment of various infectious diseases in Africa and Asia, the interest in the genus Embelia has recently increased. The genus comprises 130 species, which are mainly shrubby woody climbers distributed in tropical and subtropical areas including Africa, Eastern Asia to the Pacific Islands, and Australia $[1,2]$.
Embelia schemperi Vatke is widely used in traditional medicine as antibacterial and anthelmintic agents [3]. A gum obtained from the plant is used as a warming remedy in the treatment of dysmenorrheal, fevers, chest, and skin diseases [4]. We report here the isolation, spectroscopic identification, and antibacterial evaluation of the crude extract as well as two flavans against four selected strains of microorganisms.

\section{Experimental Section}

2.1. General. TLC was performed using precoated aluminumbacked supported silica gel $60 \mathrm{~F} 254(0.2 \mathrm{~mm}$ thickness) and glass supported silica gel $60 \mathrm{~F} 254$ ( $1.0 \mathrm{~mm}$ thickness), respectively. Flavonoids were detected on TLC stained with the aluminum chloride $\left(\mathrm{AlC}_{13}\right)$ reagent in which a positive result was indicated by the observation of pink spots visualized in vanillin. Column chromatography was carried out using silica gel 60, 70-230 mesh ASTM. The ultraviolet and visible (UVVis) spectrum was taken on Spectroscopic Genesys ${ }^{\mathrm{TM}} 2 \mathrm{PC}$ UVVis scanning spectrometer. The infrared (IR) data were recorded on a PerkinElmer model FTIR spectrometer as $\mathrm{KBr}$ 
disks. ${ }^{1} \mathrm{H}$ - and ${ }^{13} \mathrm{C}-\mathrm{NMR}$ data were obtained in DMSO- $d_{6}$ on a Bruker Avance $400 \mathrm{MHz}$.

2.2. Plant Material Collection and Identification. The stem barks of Embelia schimperi were collected from the Oromia region, Horo Guduru Wellaga Zone in Jarte woreda, Sombo kumi kebele, which is $381 \mathrm{~km}$ west of Addis Ababa on December 08, 2016. The plant was identified by the botanist Shambel Alemu, National Herbarium of Ethiopia, Addis Ababa University. The barks were cut into small pieces, air-dried, and ground into a fine powder.

2.3. Extraction and Isolation. Air-dried stem bark powder was weighed $(500 \mathrm{~g})$ and extracted exhaustively with dichloromethane/methanol (1:1) for $72 \mathrm{~h}$ at room temperature. The marc left was further extracted with $2 \mathrm{~L}$ methanol soaked for $72 \mathrm{~h}$ at room temperature. The mixture was filtered, and the filtrate was concentrated under reduced pressure and temperature of $40^{\circ} \mathrm{C}$ using rotary evaporator and afforded (20.6 g) (4.21\%) crude extract. Silica gel (150 g) was mixed with $1.5 \mathrm{~L}$ of $n$-hexane, and the slurry was used to pack the column. The crude dichloromethane/methanol $(1: 1)$ extract $(15 \mathrm{~g})$ was adsorbed on $15 \mathrm{~g}$ of silica gel and applied on column. Elution was carried out with increasing gradient of ethyl acetate in $n$-hexane. A total of 36 fractions were collected each concentrated under reduced pressure to dryness. Fractions that showed similar $R_{\mathrm{f}}$ values and the same characteristic color on TLC were combined. Fraction 16 afforded single spot (compound 1) on TLC (EtoAc/nhexane, $9: 1, R_{\mathrm{f}}$ value of $0.52,18 \mathrm{mg}$ ). Fraction 20 which showed one major spot was repurified in a small column with isocratic EtoAc/ $n$-hexane $(7: 3)$ and afforded $12 \mathrm{mg}$ of compound 2 .

2.4. Phytochemical Screening Test. Phytochemical screening tests were carried out following literature protocol [5-8].

Test for alkaloids: To $0.5 \mathrm{~g}$ of crude extract, dilute hydrochloric acid was added and filtered. Dragendorff's reagent (a solution of potassium bismuth iodide) was added slowly to the filtrate, and formation of red precipitate confirms the presence of alkaloids.

Test for flavonoids: To $0.5 \mathrm{~g}$ portion of crude extract, $10 \mathrm{~mL}$ of ethyl acetate was added and heated for $3 \mathrm{~min}$ using steam bath. The mixture was filtered, and the filtrate $(4 \mathrm{~mL})$ was mixed with $1 \mathrm{~mL}$ of dilute ammonia solution. Formation of intense yellow color ratifies the presence of flavanoids.

Test for saponins: To $0.5 \mathrm{~g}$ of crude extract, $5 \mathrm{~mL}$ of distilled water was added and shaken while heating to boil. Frothing showed the presence of saponins.

Test for phenols: To $0.5 \mathrm{~g}$ of crude extract, few drops of $2 \%$ of $\mathrm{FeCl}_{3}$ were added and the formation of bluish green to black color indicates the presence of phenols.

Test for tannins: The crude extract $(0.5 \mathrm{~g})$ was boiled in $10 \mathrm{~mL}$ of water in a test tube and filtered. To the filtrate, few drops of $0.1 \%$ ferric chloride was added to give a brownish green or a blue-black color which confirms the presence of tannins.
Test for terpenoids: Crude extract $(0.5 \mathrm{~g})$ was dissolved in $5 \mathrm{~mL}$ of methanol, and $2 \mathrm{~mL}$ of the extract was treated with $1 \mathrm{~mL}$ of 2,4-dinitrophenyl hydrazine dissolved in $100 \mathrm{~mL}$ of $2 \mathrm{M} \mathrm{HCl}$. The formation of the yellow-orange color confirms the presence of terpenoids.

Detection of phytosterols (Salkowski's test): Crude extract $(0.5 \mathrm{~g})$ was treated with a few drops of chloroform and filtered. To the filtrate, few drops of concentrated sulphuric acid was added, shaken, and allowed to stand. Appearance of the golden yellow color indicates the presence of triterpenes.

Test for glycosides (modified Borntrager's test): Crude extract $(0.5 \mathrm{~g})$ was treated with ferric chloride solution and immersed in boiling water for about 5 minutes. The mixture was cooled and extracted with equal volumes of benzene. The benzene layer was separated and treated with ammonia solution. Formation of the rose-pink color in the ammonical layer confirms the presence of anthranol glycosides.

\subsection{Antibacterial Testing}

2.5.1. Preparation of Discs Containing Extracts. The same concentrations of $20 \mu \mathrm{g} / \mathrm{mL}$ were prepared from the extract, isolated pure compounds, and the standard. The concentration was incorporated into sterile agar-disc diffusion and dried at $37^{\circ} \mathrm{C}$. The agar disc was weighed carefully for confirming exact amount of the extract and isolated pure compounds being incorporated (compared to preweighed blank discs).

2.5.2. Bacterial Culture. Escherichia coli and Proteus mirabilis which were isolated from stool specimens in the clinic were identified according to routine cultural properties and biochemical tests. Four strains of each were included in the study. A few colonies from the overnight culture of Eosin Methylene Blue (EMB) agar was transferred into approximately $4-5 \mathrm{~mL}$ Tripticase soy broth (TSB) medium. The broth was incubated at $37^{\circ} \mathrm{C}$ for $3-4$ hours, and the turbidity of suspension was adjusted to that of $0.5 \mathrm{McF}$ arland barium sulfate standard. The standard suspension was used for both qualitative and quantitative antibacterial assays.

2.5.3. Bacterial Susceptibility Testing. Standardized inoculums $(20 \mu \mathrm{g} / \mathrm{mL})$ were introduced on to the surface of sterile agar plates, and a sterile glass spreader was used for even distribution of the inoculums. A sterile agar-disc diffusion previously soaked in a known concentration of extract or pure compound $(20 \mu \mathrm{g} / \mathrm{mL}$ per disc) was carefully placed at the centre of the labeled seeded plate. The same procedure was used for all the MRSA strains used. The plates were incubated aerobically at $37^{\circ} \mathrm{C}$ and examined for zones of inhibition after $24 \mathrm{hr}$. The inhibition zones were measured with a ruler and compared with the control disc (disc containing only physiological saline).

Strains of human pathogen microorganisms used in this study were as follows: three Gram-negative bacteria Klebsiella pneumoniae, Proteus mirabilis, and Escherichia coli and 
one Gram-positive bacteria Staphylococcus aureus. The bacterial stock cultures were incubated for $24 \mathrm{hr}$ at $37^{\circ} \mathrm{C}$ on nutrient agar medium (Oromia Public Health Research Laboratory, Adama). The bacterial strains were grown in the Mueller-Hinton agar (MHA) plates at $37^{\circ} \mathrm{C}$ (the bacteria were grown in the nutrient broth at $37^{\circ} \mathrm{C}$ and maintained on nutrient agar slants at $4^{\circ} \mathrm{C}$.

The agar was melted $\left(50^{\circ} \mathrm{C}\right)$, and the microorganism cultures were then added aseptically to the agar medium at $45^{\circ} \mathrm{C}$ in plates and poured into sterile Petri dishes to give a solid plate. All these experiments were performed in duplicate. The plates were incubated for $24-48 \mathrm{hr}$ at $37^{\circ} \mathrm{C}$ for bacteria. The inhibition zones produced by the plant extracts were compared with the inhibition zones produced by commercial standard antibiotics. The minimal inhibitory concentration (MIC) was applied to the methanol extract and compound that had proved to be highly effective against microorganisms by the agar-disc diffusion method. One dilution $(20 \mu \mathrm{g} / \mathrm{mL})$ of E. shimperi extract, pure compound and standard drugs were prepared in methanol using nutrient agar tubes. Mueller-Hinton sterile agar plates were seeded with indicator bacterial strains (108 cfu) and allowed to stay at $37^{\circ} \mathrm{C}$ for $3 \mathrm{hr}$. Control experiments were carried out under similar conditions by using gentamicin for antibacterial activity as a standard drug. The zones of growth inhibition around the disks were measured after 18 to $24 \mathrm{hr}$ of incubation at $37^{\circ} \mathrm{C}$ for bacteria. The sensitivities of the microorganism species to the plant extract and isolated pure compounds were determined by measuring the sizes of inhibitory zones (including the diameter of disk) on the agar surface around the disks, and values $<6 \mathrm{~mm}$ were considered as not active against microorganisms $[9,10]$.

\section{Results and Discussion}

3.1. Phytochemical Screening Test Results. The phytochemical screening results showed absence of terpenoids, glycosides, and phytosterols in the methanol extracts whereas saponins, phenols, alkaloids, tannins, and flavonoids are present. Similarly, the $\mathrm{CH}_{2} \mathrm{Cl}_{2} / \mathrm{CH}_{3} \mathrm{OH}(1: 1)$ extract showed the absence of terpenoids, phytosterols, and glycosides whereas saponins, alkaloids, tannins, phenols, and flavonoids are present (Table 1).

3.2. Characterization of Compounds. Compound $\mathbf{1}$ was obtained as a yellowish powder (melting point $173^{\circ} \mathrm{C}$ ) isolated from $\mathrm{MeOH}$ extract with $R_{\mathrm{f}}$ value of 0.52 in EtoAc/nhexane $(9: 1)$. Its $\mathrm{UV}-\mathrm{V}$ is spectrum revealed absorption maxima at $282 \mathrm{~nm}$, suggesting the presence of $\Pi$ to $\Pi^{*}$ transition due to the presence of aromatic ring chromophore. The IR (KBr disk) spectrum showed broad vibration at $3375 \mathrm{~cm}^{-1}$ attributed to hydroxyl moiety $(\mathrm{OH})$, sharp absorption at $1600 \mathrm{~cm}^{-1}$ attributed to aromatic benzene ring, strong absorption band at $2275 \mathrm{~cm}^{-1}$ due to $\mathrm{C}-\mathrm{H}$ stretching of saturated moiety, and absorption band at $1255 \mathrm{~cm}^{-1}$ due to $\mathrm{C}-\mathrm{O}$ stretching.

The ${ }^{1} \mathrm{H}-\mathrm{NMR} \delta_{\mathrm{H}}\left(400 \mathrm{MHz}, \mathrm{DMSO}-d_{6}\right.$, Table 2$)$ spectrum revealed the presence of proton signals at $\delta_{\mathrm{H}} 5.73(1 \mathrm{H}$, $\mathrm{d}, J=1.2 \mathrm{~Hz}, \mathrm{H}-6)$ and $5.89(1 \mathrm{H}, \mathrm{d}, J=1.2 \mathrm{~Hz}, \mathrm{H}-8)$ suggest
TABle 1: Phytochemical screening test results.

\begin{tabular}{lcc}
\hline $\begin{array}{l}\text { Secondary } \\
\text { metabolites }\end{array}$ & $\begin{array}{c}\mathrm{CH}_{3} \mathrm{OH} \\
\text { extract }\end{array}$ & $\begin{array}{c}\mathrm{CH}_{2} \mathrm{Cl}_{2} / \mathrm{CH}_{3} \mathrm{OH}(1: 1) \\
\text { extract }\end{array}$ \\
\hline Saponins & + & + \\
Terpenoids & - & - \\
Phytosterols & - & - \\
Flavonoides & + & + \\
Alkaloides & + & + \\
Phenols & + & + \\
Glycosides & - & - \\
Tannins & + & + \\
\hline
\end{tabular}

+ indicates presence; - indicates absence.

the presence of two meta coupled aromatic protons that belong to a tetrasubstituted phenyl ring A. The presence of signals with $\mathrm{ABX}$ multiplicity pattern at $\delta_{\mathrm{H}} 6.88(1 \mathrm{H}$, dd, $\left.J=8.1,1.2 \mathrm{~Hz}, \mathrm{H}-6^{\prime}\right)$ and $\delta_{\mathrm{H}} 6.73(1 \mathrm{H}, \mathrm{dd}, J=2.1,8.1 \mathrm{~Hz}$, $\mathrm{H}=2^{\prime}, 5^{\prime}$ ) suggest a trisubstituted phenyl ring B. Signals at $\delta_{\mathrm{H}} 4.73(1 \mathrm{H}, \mathrm{d}, \mathrm{H}-2, J=2.2)$ and $4.01(1 \mathrm{H}, \mathrm{m}, \mathrm{H}-3)$ suggest the presence of two oxygenated methines whereas signals a peak at $\delta_{\mathrm{H}} 2.67(1 \mathrm{H}, \mathrm{dd}, J=16.5,4.5 \mathrm{~Hz}, \mathrm{H}-4 \mathrm{a})$ and at $\delta_{\mathrm{H}}$ $2.47(1 \mathrm{H}, \mathrm{dd}, J=16.5,4.5 \mathrm{~Hz}, \mathrm{H}-4 \mathrm{~b})$ suggest the presence of diasterotopic methylene protons at C-4. The above ${ }^{1} \mathrm{H}-\mathrm{NMR}$ pattern suggests that the compound has flavan skeleton with two aromatic protons (H-6 and 8) on ring $\mathrm{A}$ and three aromatic protons $\left(\mathrm{H}-2^{\prime}, 5^{\prime}\right.$, and $\left.6^{\prime}\right)$ on ring $\mathrm{B}$ and devoid of the carbonyl group at $\mathrm{C}-4$ of ring $\mathrm{C}$.

In agreement with the ${ }^{1} \mathrm{H}-\mathrm{NMR}$, the ${ }^{13} \mathrm{C}-\mathrm{NMR}$ spectrum (Table 2) revealed a total of fifteen carbon signals. The presence of two oxygenated $\mathrm{sp}^{2}$ quaternary carbons was observed at $\delta_{\mathrm{C}} 144.7\left(\mathrm{C}-3^{\prime}\right)$ and $\delta_{\mathrm{C}} 144.6\left(\mathrm{C}-4^{\prime}\right)$, suggesting the vicinal substitution pattern on ring $C$, in agreement with the $\mathrm{ABX}$ multiplicity pattern, where as the methines appear at $\delta_{\mathrm{C}} 118.5\left(\mathrm{C}-6^{\prime}\right)$ and $\delta_{\mathrm{C}} 115.1\left(\mathrm{C}-2^{\prime}, 5^{\prime}\right)$. The presence of two $\mathrm{sp}^{2}$ oxygenated quaternary carbons at $\delta_{\mathrm{C}}$ $156.7(\mathrm{C}-5)$ and $\delta_{\mathrm{C}} 156.6(\mathrm{C}-7)$ along with two upfield carbons chemical shifts at $\delta_{\mathrm{C}} 95.3$ (C-6) and $\delta_{\mathrm{C}} 94.5(\mathrm{C}-8)$ suggest that ring $\mathrm{A}$ has 5,7-dioxygenated substitution pattern. The following quaternary carbons are also clearly evident from ${ }^{13} \mathrm{C}-\mathrm{NMR}$ spectrum: $\delta_{\mathrm{C}} 99.0(\mathrm{C}-4 \mathrm{a}), \delta_{\mathrm{C}} 131.1$ $\left(\mathrm{C}-1^{\prime}\right)$, and $156.2(\mathrm{C}-8 \mathrm{a})$. Signals at $\delta_{\mathrm{C}} 78.4(\mathrm{C}-2)$ and $\delta_{\mathrm{C}}$ $65.2(\mathrm{C}-3)$ are clearly evident due to the presence of $\mathrm{sp}^{3}$ oxygenated methines C- 2 and C-3 of ring C. Moreover, the presence of one methylene (also supported by DEPT-135 pointing down) observed at $\delta_{\mathrm{C}} 28.6(\mathrm{C}-4)$ is in good agreement with spectral data, and the structure of the compound has flavan skeleton.

The COSY spectrum showed a correlation between protons at $\delta_{\mathrm{H}} 4.01(\mathrm{H}-3)$ and $\delta_{\mathrm{H}} 4.73(\mathrm{H}-2)$ in agreement with the substitution pattern in ring $\mathrm{C}$. Similarly, aromatic proton at $\delta_{\mathrm{H}} 5.73(\mathrm{H}-6)$ showed HMBC correlations with $\mathrm{C}-5,7$, and 8 at $\delta_{\mathrm{C}} 156.8,156.3$, and 94.5 , whereas aromatic proton at $\delta_{\mathrm{H}} 5.89(\mathrm{H}-8)$ showed HMBC correlations with C-6, 7, 8a, and $4 \mathrm{a}$ at $\delta_{\mathrm{C}} 95.3,156.3,156.2$, and 99.0 in agreement with the substitution pattern in ring $\mathrm{A}$. The methylene proton at $\delta_{\mathrm{H}} 2.67(\mathrm{H}-4)$ showed HMBC correlations with the $\delta_{\mathrm{C}} 78.4(\mathrm{C}-2), 65.2$ (C-3), $156.2(8 \mathrm{a})$, and 99.0 (5a) in agreement with the substitution pattern in ring $\mathrm{C}$. 
TABLE 2: ${ }^{1} \mathrm{H}$-NMR, ${ }^{13} \mathrm{C}$-NMR, and 2D spectral data of compound $\mathbf{1}$ in DMSO- $d_{6}$.

\begin{tabular}{|c|c|c|c|c|}
\hline Position & ${ }^{1} \mathrm{H}-\mathrm{NMR}$ & ${ }^{13} \mathrm{C}-\mathrm{NMR}$ & COSY & HMBC \\
\hline 2 & $4.73(1 \mathrm{H}, \mathrm{s}, \mathrm{H}-2)$ & 78.5 & $\mathrm{H} 2-\mathrm{H} 3$ & $\mathrm{H}_{2}-\mathrm{C}_{1,3,4}^{\prime}$ \\
\hline 3 & $4.01(1 \mathrm{H}, \mathrm{m}, J=2.1 \mathrm{~Hz}, \mathrm{H}-8)$ & 65.4 & $\mathrm{H} 2-\mathrm{H} 3$ & $\mathrm{H}_{3}-\mathrm{C}_{1,2,4,4 \mathrm{a}}^{\prime}$ \\
\hline 4 & $2.67(2 \mathrm{H}, \mathrm{dd}, J=16.5,4.5 \mathrm{~Hz}, \mathrm{H}-4)$ & 28.7 & $\mathrm{H} 3-\mathrm{H} 4$ & $\mathrm{H}_{4}-\mathrm{C}_{2,3,4 \mathrm{a}, 5,8 \mathrm{a}}$ \\
\hline $4 \mathrm{a}$ & - & 99.0 & & \\
\hline 5 & - & 156.9 & & \\
\hline 6 & $5.73(1 \mathrm{H}, \mathrm{d}, J=1.2 \mathrm{~Hz})$ & 95.6 & & $\mathrm{H}_{6}-\mathrm{C}_{4 a}, 5,7,8$ \\
\hline 7 & - & 156.7 & & \\
\hline 8 & $5.89(1 \mathrm{H}, \mathrm{d}, J=1.2 \mathrm{~Hz})$ & 94.6 & & $\mathrm{H}_{8}-\mathrm{C}_{6,7,8 \mathrm{a}, 4 \mathrm{a}}$ \\
\hline $8 \mathrm{a}$ & - & 156.2 & & \\
\hline $1^{\prime}$ & - & 131.1 & & \\
\hline $2^{\prime}$ & $6.67(1 \mathrm{H}, \mathrm{dd}, J=8.1,2.1 \mathrm{~Hz})$ & 115.2 & & \\
\hline $3^{\prime}$ & - & 144.6 & & \\
\hline $4^{\prime}$ & - & 144.7 & & \\
\hline $5^{\prime}$ & & 115.4 & & \\
\hline $6^{\prime}$ & $6.88(1 \mathrm{H}, \mathrm{dd}, J=8.1,2.1 \mathrm{~Hz})$ & 118.4 & $\mathrm{H} 5^{\prime}-\mathrm{H} 6^{\prime}$ & $\mathrm{H}_{6}{ }^{\prime}-\mathrm{C}_{1}{ }^{\prime},{ }_{3}{ }^{\prime}{ }^{\prime},{ }^{\prime}{ }^{\prime}$ \\
\hline
\end{tabular}

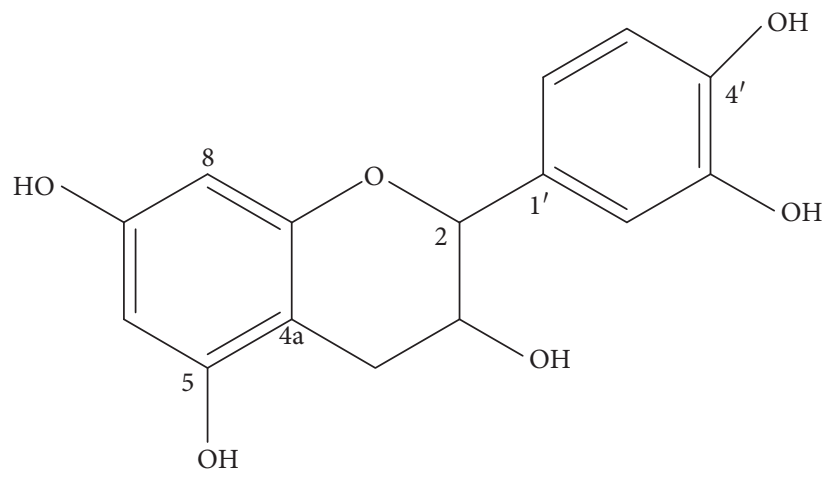

The HMBC correlations between the proton at $\delta_{\mathrm{H}} 6.88$ $\left(\mathrm{H}-6^{\prime}\right)$ and $\delta_{\mathrm{H}} 6.67\left(\mathrm{H}-5^{\prime}\right)$ with that of $\delta_{\mathrm{C}} 78.4(\mathrm{C}-2)$ and two oxygenated $\mathrm{sp}^{2}$ vicinal quaternary carbons at $\delta_{\mathrm{C}} 144.6\left(\mathrm{C}-4^{\prime}\right)$ and $144.7\left(\mathrm{C}-3^{\prime}\right)$ further support the $\mathrm{ABX}$ multiplicity pattern of ring $\mathrm{B}$ confirming the exact location of the two hydroxyl groups to be at $\mathrm{C}-3^{\prime}$ and $4^{\prime}$ positions. Thus, based on the above spectral data the structure of the compound was found to be $3,5,7,3^{\prime}, 4^{\prime}$-pentahydroxyflavan (1) similar to the previously identified compound epicatechin (1) with various pharmacological activity $[11,12]$.

Compound 2 was isolated as orange powder with $R_{\mathrm{f}}$ value of 0.75 in EtoAc/methanol (9:1). The UV-Vis spectrum showed absorption maxima at $\lambda_{\max }$ (in $\mathrm{MeOH}$ ) at $282 \mathrm{~nm}$, suggesting the presence of $\Pi$ to $\Pi^{*}$ transition due to the presence of aromatic ring chromophore. The IR $(\mathrm{KBr}$ disk) spectrum showed broad vibration at $3254 \mathrm{~cm}^{-1}$ due to the presence of the hydroxyl group, sharp absorption at $2933 \mathrm{~cm}^{-1}$ due to the saturated group, sharp absorption at $1599 \mathrm{~cm}^{-1}$ attributed to the aromatic benzene ring, strong absorption band at $2275 \mathrm{~cm}^{-1}$ due to the saturated group $\mathrm{C}-\mathrm{H}$ stretching, and strong absorption band at $1132 \mathrm{~cm}^{-1}$ due to C-O stretching. All ${ }^{1} \mathrm{H}-\mathrm{NMR}$ and ${ }^{13} \mathrm{C}-\mathrm{NMR}$ features of compound $\mathbf{2}$ are very close to that of compound $\mathbf{1}$ (all NMR data are summarized in Table 3) except that the ${ }^{1} \mathrm{H}$-NMR spectra shows a $\mathrm{AA}^{\prime} \mathrm{XX}^{\prime}$ spin pattern with two pair of doublets at $\delta_{\mathrm{H}} 6.88\left(2 \mathrm{H}, \mathrm{dd}, J=8.1,1.2 \mathrm{~Hz}, \mathrm{H}-2^{\prime}, 6^{\prime}\right)$ and $6.73\left(2 \mathrm{H}, \mathrm{dd}, J=2.1,8.1 \mathrm{~Hz}, \mathrm{H}-3^{\prime}, 5^{\prime}\right)$, suggesting a $1^{\prime}, 4^{\prime}$ disubstituted ring $B$. In agreement with the ${ }^{1} \mathrm{H}-\mathrm{NMR}$ pattern, the ${ }^{13} \mathrm{C}$-NMR revealed only one oxygenated $\mathrm{sp}^{2}$ quaternary carbon at $\delta_{\mathrm{C}} 144.7\left(\mathrm{C}-4^{\prime}\right)$, where the methines appear at $118.5\left(\mathrm{C}-2^{\prime}\right.$ and $\left.6^{\prime}\right)$ and $115.1\left(\mathrm{C}-3^{\prime}\right.$ and $\left.5^{\prime}\right)$, suggesting the presence of symmetry in ring $\mathrm{B}$. Thus, based on the above spectral data, the structure of compound 2 was found to be $3,5,7,4^{\prime}$-tetrahydroxy flavan (2).

3.3. Antibacterial Activity. The antibacterial activity of the extract and isolated compounds of $E$. shimperi were examined at a concentration of $20 \mu \mathrm{g} / \mathrm{mL}$ against four pathogenic bacterial strains: one Gram-positive Staphylococcus aureus and three Gram-negative Escherichia coli, Klebsiella pneumoniae, and Proteus mirabilis. Antibacterial potential of crude extract and isolated pure compound were assessed in terms of zone of inhibition of bacterial growth. The results of the antibacterial activities are presented in Table 4 .

As shown in Table 4, the results revealed that the isolated compounds showed promising antibacterial activity against Staphylococcus aureus, E. coli, Proteus mirabilis and Klebsiella pneumoniae. Epicatechin (1) exhibited comparable antibacterial activity against $S$. aureus to that of gentamicin, with the zone of inhibition diameter $15 \mathrm{~mm}$. This result shows that Epicatechin (1) and the genus Embelia are potential candidates 
TABLE 3: ${ }^{1} \mathrm{H}$-NMR and ${ }^{13} \mathrm{C}$-NMR spectral data of compound 2 in DMSO- $d_{6}$.

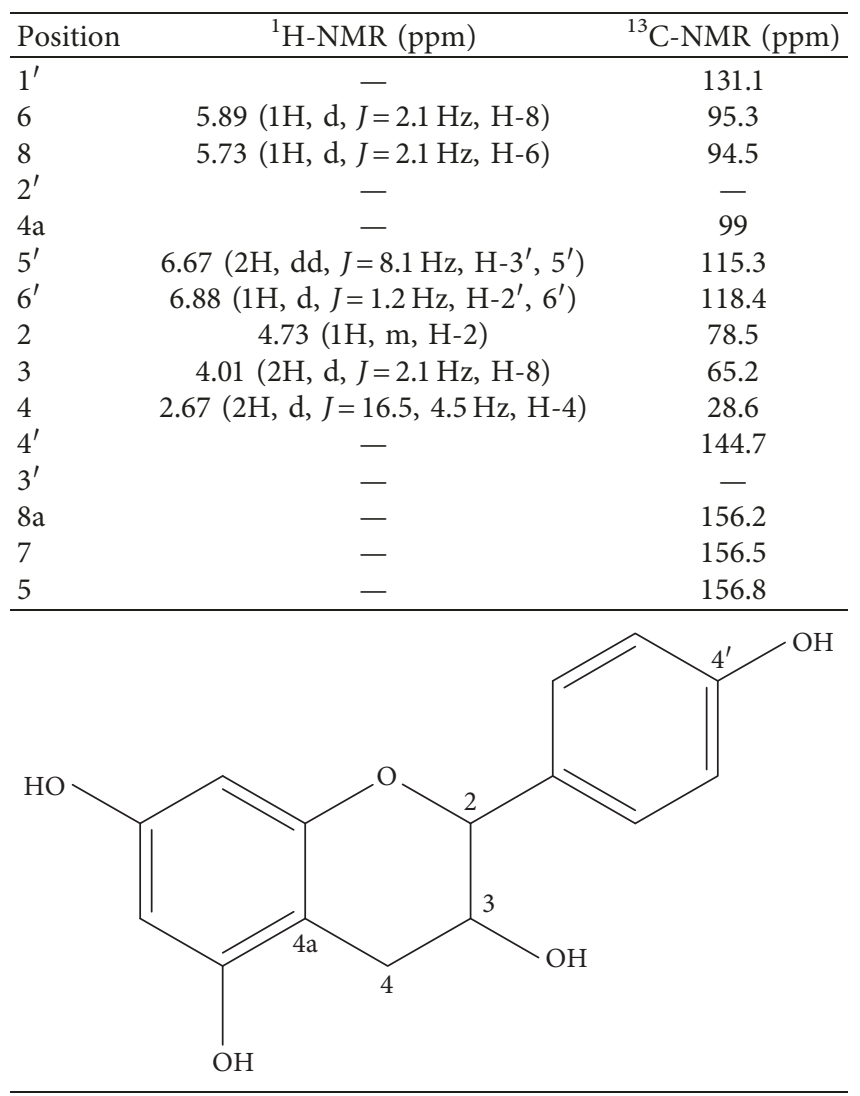

TABLE 4: Zone of bacterial growth inhibition ( $\mathrm{mm}$ ) for crude extract and isolated compounds from the stem bark of E. schemperi.

\begin{tabular}{lcccc}
\hline Sample & $\begin{array}{c}\text { Staphylococcus } \\
\text { aureus }\end{array}$ & $\begin{array}{c}\text { Escherichia } \\
\text { coli }\end{array}$ & $\begin{array}{c}\text { Proteus } \\
\text { mirabilis }\end{array}$ & $\begin{array}{c}\text { Klebsiella } \\
\text { pneumonia }\end{array}$ \\
\hline $\begin{array}{l}\text { Methanol } \\
\text { extract }\end{array}$ & $n$ & $n$ & $n$ & $n$ \\
Compound 2 & 11 & 13 & 10 & 10 \\
Compound 1 & 15 & 12 & 6 & 11 \\
Gentamicin & 15 & 15 & 15 & 15 \\
\hline
\end{tabular}

$n \leq 6$ is null, and $n>6$ is sensitive.

for development of antibacterial drug against Staphylococcus aureus.

\section{Conclusions}

This work resulted in the isolation of two flavan compounds $(\mathbf{1}, \mathbf{2})$ isolated for the first time from the stem bark of Embelia schimperi. The structures of the compounds were characterized on the basis of spectral data (UV-Vis, ${ }^{1} \mathrm{H}-\mathrm{NMR}$, ${ }^{13}$ C-NMR, DEPT-135, HMBC, HSQC, COSY, and IR) as well as in comparison with the literature report. The antibacterial test results revealed that the isolated compounds showed promising antibacterial activity against Staphylococcus aureus, E. coli, Proteus mirabilis, and Klebsiella pneumoniae. Epicatechin (1) exhibited comparable $(15 \mathrm{~mm}$ zone of inhibition) antibacterial activity against $S$. aureus to that of gentamicin ( $15 \mathrm{~mm}$ zone of inhibition). Compound 2 also exhibited promising antibacterial activity against $S$. aureus and E. coli and 11 and $13 \mathrm{~mm}$ zone of inhibition, respectively, compared to that of gentamicin $(15 \mathrm{~mm}$ zone of inhibition).

\section{Conflicts of Interest}

The authors declare that there are no conflicts of interest regarding the publication of this paper.

\section{Acknowledgments}

The authors acknowledge Adama Science and Technology University (ASTU) Office of Graduate Studies for offering research grant to the MSc candidate Babe Guyasa and Oromia Public Health Research Capacity Building and Quality Assurance Laboratory for antibacterial assay. The authors are also grateful to Department of Chemistry, Addis Ababa University, for permitting them to access their $400 \mathrm{MHz}$ NMR machine.

\section{References}

[1] J. Rondevaldova, O. Leuner, A. Teka et al., "In vitro antistaphylococcal effects of Embelia schimperi extracts and their component embelin with oxacillin and tetracycline," Evidence-Based Complementary and Alternative Medicine, vol. 2015, Article ID 175983, 7 pages, 2015.

[2] Y. Debebe, M. Tefera, W. Mekonnen et al., "Evaluation of anthelmintic potential of the Ethiopian medicinal plant Embelia schimperi Vatke in vivo and in vitro against some intestinal parasites," BMC Complementary and Alternative Medicine, vol. 15, no. 1, p. 187, 2015.

[3] A. R. Ndhlala, H. M. Ghebrehiwot, B. Ncube et al., "Antimicrobial, anthelmintic activities and characterisation of functional phenolic acids of Achyranthes aspera Linn: a medicinal plant used for the treatment of wounds and ringworm in East Africa," Frontiers in Pharmacology, vol. 6, p. 274, 2015.

[4] N. S. Ncube, A. J. Afolayan, and A. I. Okoh, "Assessment techniques of antimicrobial properties of natural compounds of plant origin: current methods and future trends," African Journal of Biotechnology, vol. 7, no. 12, pp. 1797-1806, 2008.

[5] O. O. Debiyi and F. A. Sofowora, "Phytochemical screening of Nigerian medical plants II," Lloydia, vol. 41, no. 3, pp. 234246, 1978.

[6] T. S. Roopashree, R. Dang, R. H. S. Rani, and C. Narendra, "Antibacterial activity of antipsoriatic herbs: Cassia tora, Momordica charantia and Calendula officinalis," International Journal Applied Research in Natural Products, vol. 1, no. 3, pp. 20-28, 2008.

[7] G. E. Trease and W. C. Evans, "Phenols and phenolic glycosides," in Textbook of Pharmacognosy, vol. 12, pp. 343-383, Balliese, Tindall and Co Publishers, London, UK, 1989.

[8] A. Sofowora, Phytochemical Screening of Medicinal Plants and Traditional Medicine in Africa, Spectrum Books Ltd., Ibadan, Nigeria, 1993.

[9] K. O. Akinyemi, O. Oladapo, C. E. Okwara, C. C. Ibe, and K. A. Fasure, "Screening of crude extracts of six medicinal plants used in South-West Nigerian unorthodox medicine for anti-methicillin resistant Staphylococcus aureus activity," BMC Complementary and Alternative Medicine, vol. 5, no. 1, pp. 1-7, 2005. 
[10] A. D. Khosravi and A. Behzadi, "Evaluation of the antibacterial activity of the seed hull of Quercus brantii on some gram negative bacteria," Pakistan Journal of Medical Sciences, vol. 22, no. 4, pp. 429-432, 2006.

[11] P. H. Dang, H. X. Nguyen, N. T. Nguyen, H. N. Thi Le, and M. T. T. Nguyen, " $\alpha$-glucosidase inhibitors from the stems of Embelia ribes," Phytotheraphy Research, vol. 28, no. 11, pp. 1632-1636, 2014.

[12] M. T. Huang and T. Ferraro, "Phenolic compounds in food and their effect on health," in ACS Symposium Series, M. T. Huang, C. T. Ho, and C. Y. Lee, Eds., American Chemical Society, Washington, DC, USA, 1992. 

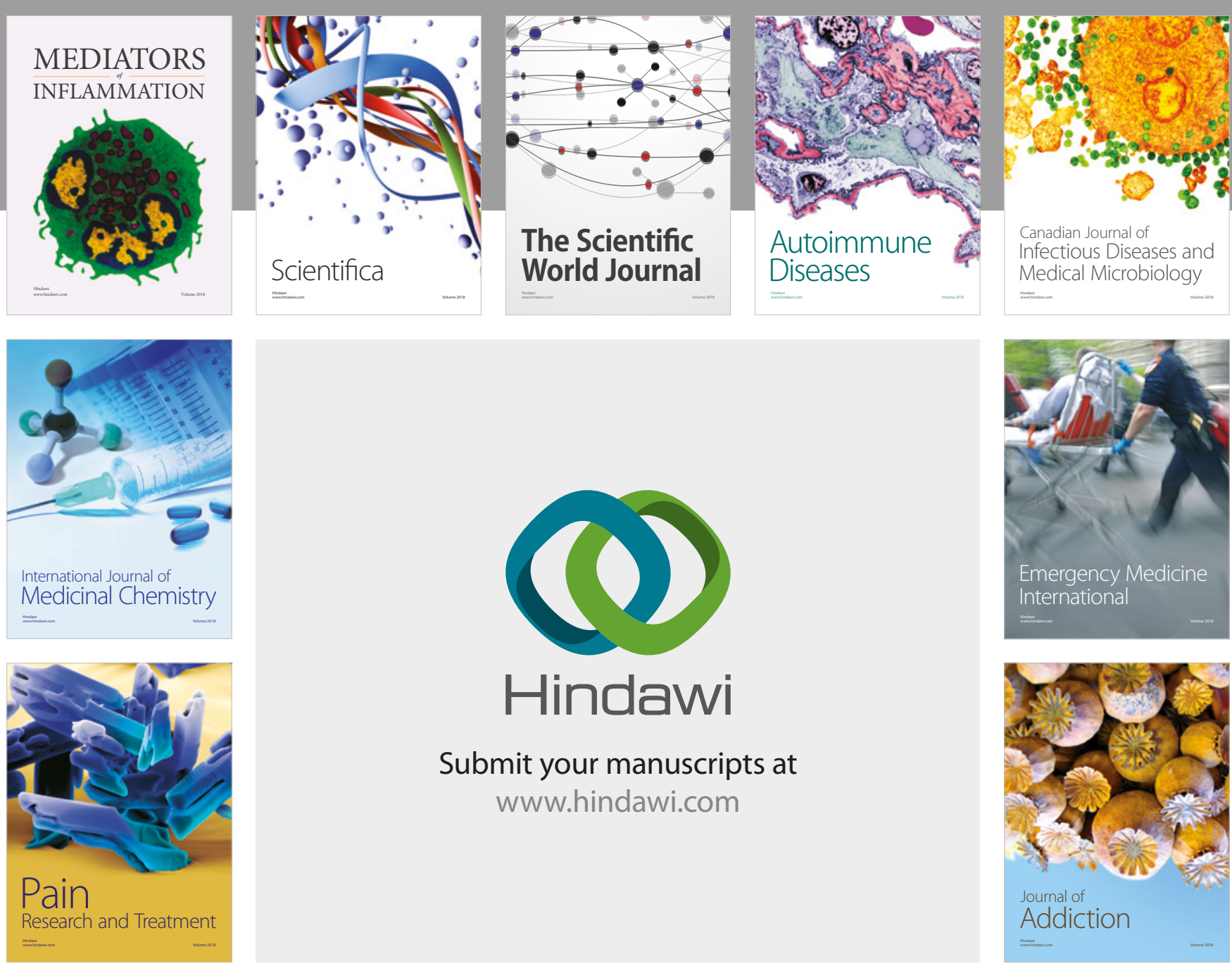

Canadian Journal of
Infectious Diseases and Medical Microbiology

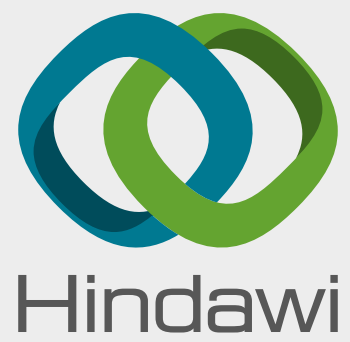

Submit your manuscripts at

www.hindawi.com
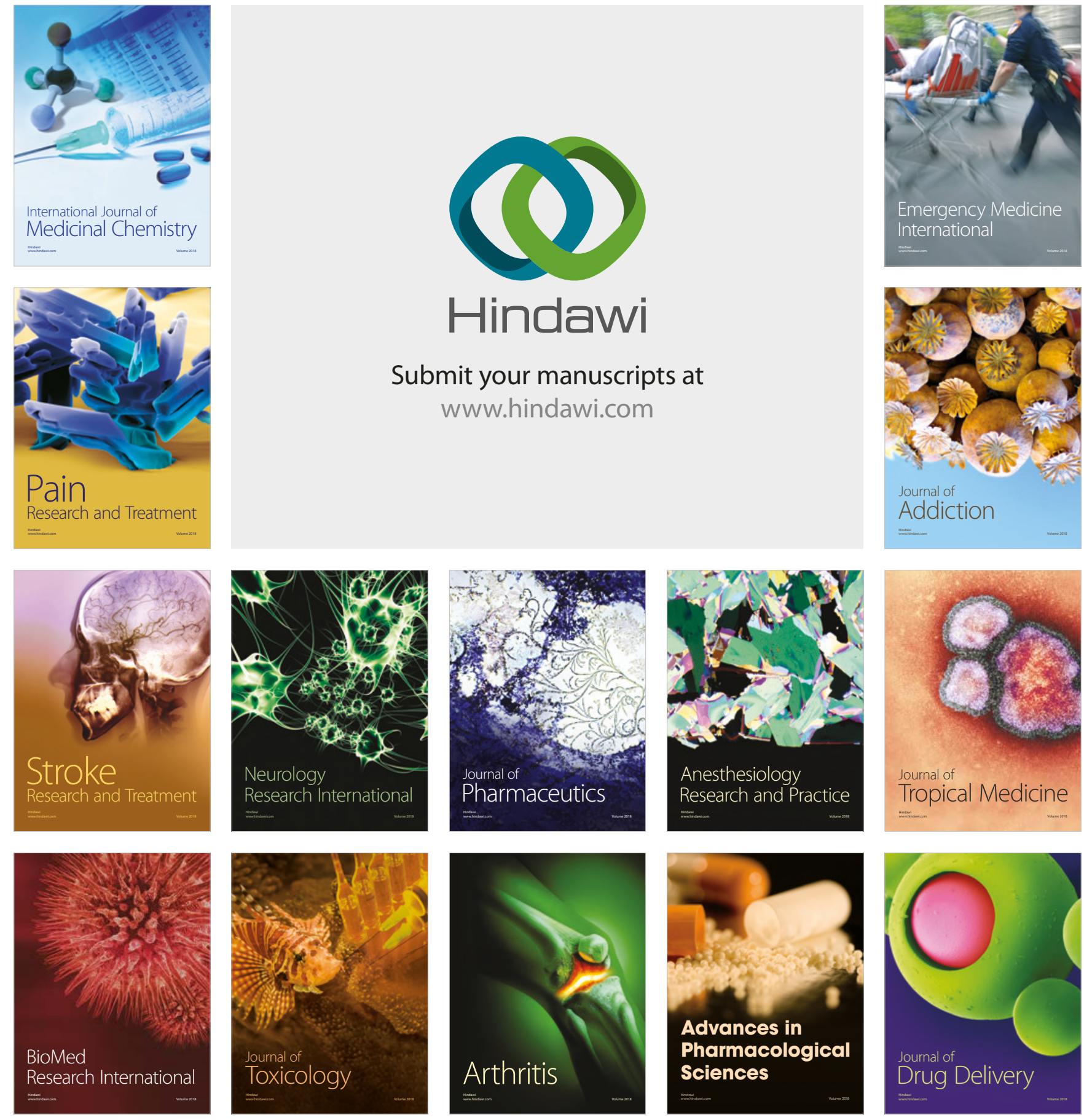